\title{
The Effects of Magnetic Resonance Imaging (MRI) on Some Properties of Acrylic Resin Denture Base Materials
}

\author{
Amer A. Taqa*, Ammar Kh. Al-Noori, Ahmed Issam Jasum Al-Khyaat \\ Department of Prosthodontic, Dentistry College, Mosul University \\ *Corresponding author: amertaqa@hotmail.com
}

Received May 1, 2013; Revised August 13, 2013; Accepted August 14, 2013

\begin{abstract}
This study aims to evaluate the effect of MRI on some physical, chemical, and mechanical properties of acrylic resin denture base materials. Four hundred fifty four samples were the total no. of sample, the samples were divided into two groups each group contain two hundred twenty seven, the $1^{\text {st }}$ sample group were pink and $2^{\text {nd }}$ groups clear heat cured acrylic resin, then the two groups is divided into four sub-groups, follow that the samples were exposed to magnetic resonance image at three different periods of time $(5,15,30)$ minutes within control group respectively and samples tested for rock well, tensile strength surface roughness, water sorption, residual monomer, color change spectrophotometer and dimensional accuracy. The results obtained show that there was a change in the physical properties heat cured acrylic resin weather it is pink or clear after exposure to MRI and this change happened at different levels and variable degree, also it has shown that there was a slight tendency to change the order of an arrangement of atoms of atoms within each molecule with no well and clear evidence of chemically altering of the main material itself, at least at the circumstances of the experiment. The study concluded that the exposure acrylic to MRI at different periods of time lead to altering of physical properties and at different levels of significance.
\end{abstract}

Keywords: MRI, PMMA, denture base, hardness, tensile strength

Cite This Article: Amer A. Taqa, Ammar Kh. Al-Noori, and Ahmed Issam Jasum Al-Khyaat, "The Effects of Magnetic Resonance Imaging (MRI) on Some Properties of Acrylic Resin Denture Base Materials." American Journal of Medical Sciences and Medicine 1, no. 4 (2013): 62-65. doi: 10.12691/ajmsm-1-4-3.

\section{Introduction}

Magnetic resonance imaging (MRI) is a non invasive medical test that helps physicians in the diagnosis and treat medical conditions and provide detailed pictures of organs, soft tissue, bone and other body structure [1].

The hydrogen nuclei in the patient, protons, behave like tiny moments since hydrogen makes up $80 \%$ of all atoms found in the human body and exhibiting a "magnetic moment", under normal circumstances and each has a north and south pole [2].

Research carried out date suggests that there are no adverse effects caused by short term exposure of head to static magnetic field up to "2" tesla T ( each T-10000 of earth gravity) whole body exposure should not exceed 4T, since most of medical research not exceed "2T" [3].

Magnetic biological research deals with the interaction of biological systems with neck static and/or on frequency ultra-low intensity electromagnetic fields with and/or via possible phenomena [4].

- Crystallization of iron-bearing magnetic monoparticles in the tissue of organisms.

- Possible existence of long-lived rotational states of some molecules inside protein parts.
- Bending and releasing electrons up to new levels of energy states.

Chemical shift results and it is evaluation parameter via NMR arising due to the electronic environment around nuclei, since the magnetic field are not equal electron transition happened [5].

Iron atoms are ferromagnetic material, which are easily to be lined up under the action of external magnetic field due to strong interaction between atoms which was called "exchange forces" [6].

MRI scanners are very useful for defining identical changes in material in three orthogonal planes with no risk of any interaction in case of "human-material" experiment [7].

The aim of this study was to evaluate the effect of exposure to Magnetic Resonance Imaging at different periods of times on mechanical, properties of acrylic resin materials.

\section{Materials and Methods}

In this study we used two types of acrylic resin Pink, Clear both are heat cured acrylic resin, both types are important denture base material. The total numbers of specimens were four hundred fifty four, the samples were 
divided into two groups each group contains two hundred twenty seven:

1. $1^{\text {st }}$. Group samples were "Pink" heat cured acrylic resin.

2. $2^{\text {nd }}$. Group samples were "Clear" heat cured acrylic resin.

Then, the total no. of samples of these two main groups were divided into four sub-groups, each sample were cured according to ADA specification " No.13, 2009"., Samples were cured for 90 minutes in $70^{\circ} \mathrm{C}$ follow by 30 minute in $100^{\circ} \mathrm{C}$ using thermostatically controlled curing unit, after that the samples have incubated into distilled water at $37\left(1^{\circ} \mathrm{C}\right.$ for two days for conditioning before testing (ADA specification), follow that samples were exposed to MRI at three different time periods $(5,15,30)$ minutes respectively, and at end of each period of time, samples were tested for Rock Well hardness, tensile strength, color change, dimension accuracy, residual monomer, surface roughness, water sorption."

The samples preparation starts by preparing a mold by investing a hard elastic foil , then water and stone mixed in a ratio of 100:23 powder-water, with manual mixing for (10-20) second, mixture placed in a flask, the two halves were closed after good vibration, left for one hour for complete setting, wax elimination was done by immersing the metal flask in boiling water for (4) minutes [8].

Each specimen after complete finishing and polishing well placed inside distilled water for condition before testing, then samples placed inside (MRI) device Philips MRI device and tested at different periods of time (5, 15, 30) min.

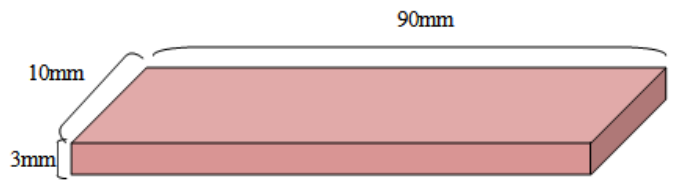

Figure 1. Tensile testing sample dimensions

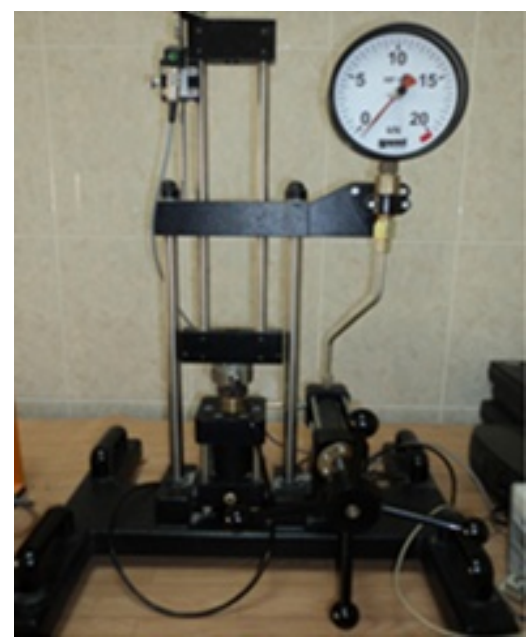

Figure 2. Gunt universal testing machine

Samples used for tensile strength procedure will be at dimension of " $90 * 10 * 3(0.3 " \mathrm{~mm}$. according to ADA specification No.12 as seen in Figure 1, and the samples were tested by use of (Gunt universal testing machine) as seen in Figure 2 and Figure 3, as specimens were grasped by two arms of machine and pulling force will start at room temperature and result were recorded on the computer, forces of failure was recorded in Newton (N) and by formula.

$$
\text { Tensile strength }=F M / A(M M)^{2}-(9)
$$

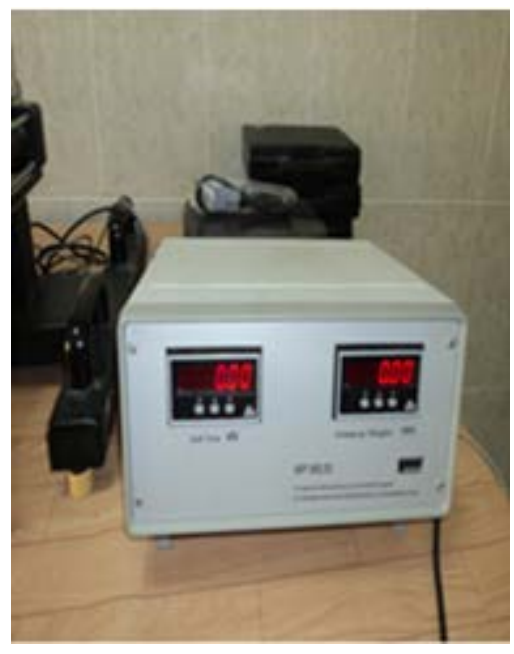

Figure 3. Gunt universal testing machine

Samples used for indentation (Rock Well) hardness test prepared with dimensions of $(30 * 15 * 3(0.03)$ as shown in Figure 4, random five readings were taken and the means of this reading were taken. The test was done by using "digital Rock Well hardness" tester Figure 5 and the indenter used in the form of round steel ball of $1 / 4$ inch in diameter with a load of $60 \mathrm{~kg} / \mathrm{MM}^{2}$ and with time up to (15-20) second.

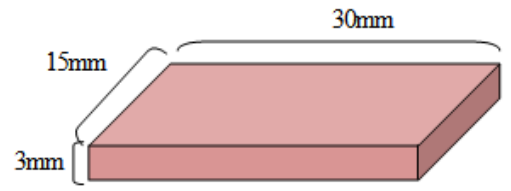

Figure 4. Indentation Hardness testing sample dimensions
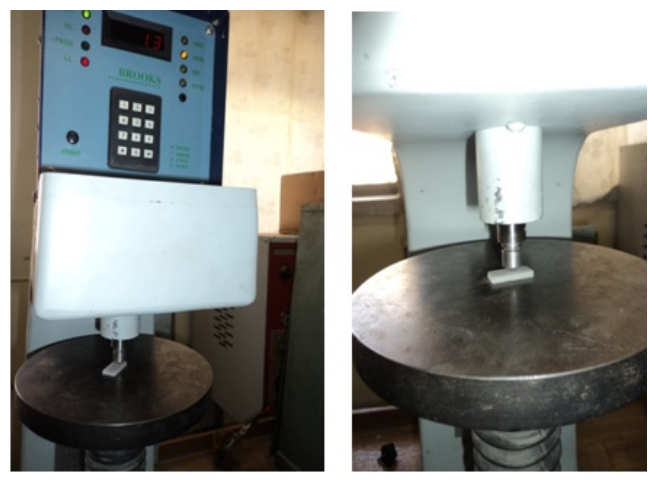

Figure 5. Digital Rock-Well hardness tester

\section{Results}

Tensile strength means and standard deviation for the tested groups at different period of time 5, 15, $30 \mathrm{~min}$. respectively within the control group for both Pink and Clear acrylic resin as shown in Figure 6. One way ANOVA analysis of variance shown in Table 1 and Duncan's multiple range test as shown in Figure 6 for two types of acrylic demonstrated at $\mathrm{P} \leq 0.05$ a significant difference at $\mathrm{P} \leq 0.05$ in tensile strength for both types of 
acrylic Pink and Clear at different periods of time 5, 15, 30minutes within the control group. Since Figure 6-A shown a higher means of in tensile strength for $15 \mathrm{~min}$. sub-group while Figure 6-B shown a higher means of 15 min. Sub-group also than other tested sub-groups, paired sample T-test for both Pink, Clear acrylic comparing at four periods of time as showed in Table 2, a significant difference at four periods of time between Pink, Clear acrylic. Rock Well indentation hardness means, stander. deviation for the tested group of 5, 15, 30 minutes respectively within the control for Pink, Clear is shown in Figure 7.

Table 1. Analysis of variance (ANOVA) (Tensile Strength)

\begin{tabular}{|c|c|c|c|c|c|c|}
\hline $\begin{array}{c}\text { Acrylic } \\
\text { Type }\end{array}$ & SOV & SS & df & MS & F-value & p-value \\
\hline \multirow{4}{*}{ Pink } & $\begin{array}{c}\text { Between } \\
\text { Groups }\end{array}$ & 0.297 & 3 & 0.099 & \multirow{2}{*}{482.626} & \multirow{2}{*}{$0.000 *$} \\
\cline { 2 - 5 } & $\begin{array}{c}\text { Within } \\
\text { Groups }\end{array}$ & 0.003 & 16 & 0.001 & & \\
\cline { 2 - 6 } Total & 0.300 & 19 & & & \multirow{2}{*}{5177.977} & $0.000 *$ \\
\hline \multirow{4}{*}{ Clear } & $\begin{array}{c}\text { Between } \\
\text { Groups }\end{array}$ & 4.505 & 3 & 1.502 & & \\
\cline { 2 - 5 } & $\begin{array}{c}\text { Within } \\
\text { Groups }\end{array}$ & 0.005 & 16 & 0.001 & & \\
\cline { 2 - 5 } & Total & 4.510 & 19 & & & \\
\hline
\end{tabular}

Table 2. Student's t-test (Tensile Strength)

\begin{tabular}{|c|c|c|c|c|c|c|c|}
\hline Group & Acrylic & No. & Mean & $\pm \mathrm{SD}$ & t-value & df & $p$-value \\
\hline \multirow{2}{*}{ Control } & Pink & 5 & 0.440 & 0.012 & \multirow{2}{*}{16.837} & \multirow{2}{*}{8} & \multirow{2}{*}{$0.000 *$} \\
\hline & Clear & 5 & 0.314 & 0.011 & & & \\
\hline \multirow{2}{*}{$5 \mathrm{~min}$} & Pink & 5 & 0.418 & 0.008 & \multirow{2}{*}{-83.168} & \multirow{2}{*}{8} & \multirow{2}{*}{$0.000 *$} \\
\hline & Clear & 5 & 0.944 & 0.011 & & & \\
\hline \multirow{2}{*}{15 min } & Pink & 5 & 0.666 & 0.015 & \multirow{2}{*}{-69.892} & \multirow{2}{*}{8} & \multirow{2}{*}{$0.000 *$} \\
\hline & Clear & 5 & 1.522 & 0.023 & & & \\
\hline \multirow{2}{*}{30 min } & Pink & 5 & 0.338 & 0.019 & \multirow{2}{*}{-87.039} & \multirow{2}{*}{8} & \multirow{2}{*}{$0.000^{*}$} \\
\hline & Clear & 5 & 1.404 & 0.019 & & & \\
\hline
\end{tabular}

* Significant difference existed at $5 \%$ level

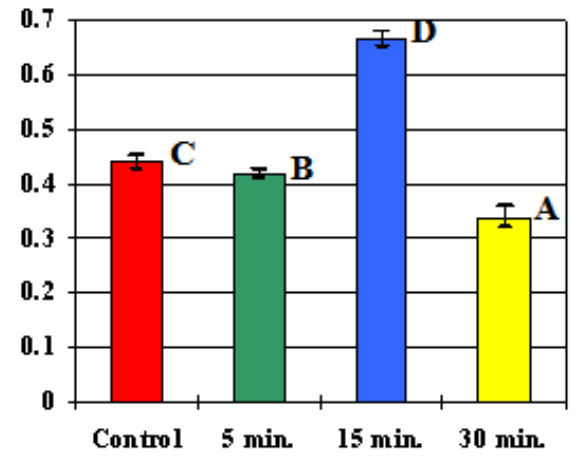

A. Pink
Table 3. Analysis of variance (ANOVA) (Rockwell Hardness Value)

\begin{tabular}{|c|c|c|c|c|c|c|}
\hline $\begin{array}{c}\text { Acrylic } \\
\text { Type }\end{array}$ & SOV & SS & df & MS & \multicolumn{1}{|c|}{$\begin{array}{c}\text { F- } \\
\text { value }\end{array}$} & $\begin{array}{c}\text { p- } \\
\text { value }\end{array}$ \\
\hline \multirow{4}{*}{ Pink } & $\begin{array}{c}\text { Between } \\
\text { Groups }\end{array}$ & 442.212 & 3 & 147.404 & \multirow{2}{*}{230.139} & $0.000^{*}$ \\
\cline { 2 - 6 } & $\begin{array}{c}\text { Within } \\
\text { Groups }\end{array}$ & 10.248 & 16 & 0.641 & & \multirow{2}{*}{$0.000^{*}$} \\
\cline { 2 - 6 } Clear & Total & 452.460 & 19 & & & \\
\hline \multirow{3}{*}{} & $\begin{array}{c}\text { Between } \\
\text { Groups }\end{array}$ & 186.690 & 3 & 62.230 & \multirow{2}{*}{46.182} & \\
\cline { 2 - 6 } & $\begin{array}{c}\text { Within } \\
\text { Groups }\end{array}$ & 21.560 & 16 & 1.348 & & \\
\cline { 2 - 6 } & Total & 208.250 & 19 & \multicolumn{3}{|c|}{} \\
\hline
\end{tabular}

* Significant difference existed at 5\% level.

SOV: Source of Variance; SS: Sum of Squares; df: Degree of Freedom; MS: Mean Square.

Table 4. Student's t-test (Rockwell Hardness Value)

\begin{tabular}{|c|c|c|c|c|c|c|c|}
\hline Group & Acrylic & No. & Mean & + SD & t-value & df & p-value \\
\hline \multirow{2}{*}{ Control } & Pink & 5 & 220.400 & 1.140 & \multirow{2}{*}{-20.115} & \multirow{2}{*}{8} & \multirow{2}{*}{$0.000^{*}$} \\
\cline { 2 - 6 } & Clear & 5 & 244.200 & 2.387 & & & \\
\hline \multirow{2}{*}{5 min } & Pink & 5 & 219.200 & 1.304 & \multirow{2}{*}{119.546} & \multirow{2}{*}{8} & \multirow{2}{*}{$0.000^{*}$} \\
\cline { 2 - 6 } & Clear & 5 & 126.600 & 1.140 & & & \\
\hline \multirow{2}{*}{15 min } & Pink & 5 & 254.400 & 1.140 & \multirow{2}{*}{25.200} & \multirow{2}{*}{8} & $0.000^{*}$ \\
\cline { 2 - 6 } 30 min & Clear & 5 & 229.200 & 1.924 & & & \\
\hline \multirow{2}{*}{3} & Pink & 5 & 229.600 & 1.140 & \multirow{2}{*}{26.163} & \multirow{2}{*}{8} & $0.000^{*}$ \\
\cline { 2 - 5 } & Clear & 5 & 207.400 & 1.517 & & & \\
\hline
\end{tabular}

* Significant difference existed at $5 \%$ level

One way ANOVA analysis of variance as in Table 3 and Duncan's multiple range at $\mathrm{P} \leq 0.05$ shown significant differences in both types of acrylic Pink, Clear Figure 7-A shows a high means for 30 min sub-group of Pink acrylic, while Figure 7-B shown a higher means for 15 minute sub-group than other tested sub-groups. Paired sample Ttest for both Pink, Clear acrylic group comparing means of hardness at four different periods of time as in Table 4 a significant difference in hardness mean at four periods.

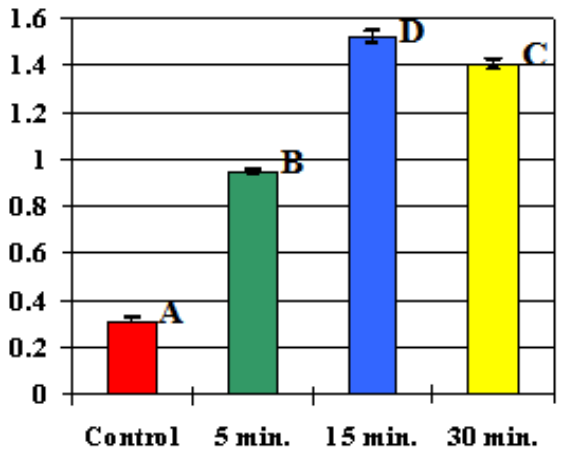

\section{B. Clear}

Figure 6 A-B. Descriptive statistics and Duncan's Multiple Range Test of tensile strength test

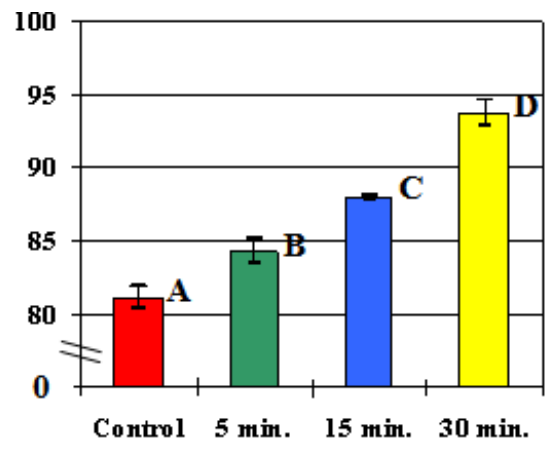

A. Pink

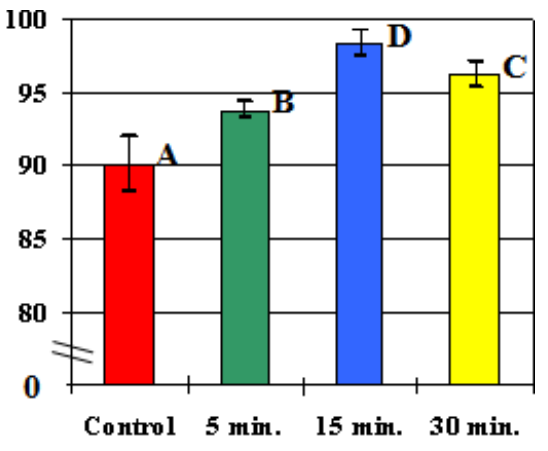

B. Clear

Figure 7 A-B. Descriptive statistics and Duncan's Multiple Range Test.One way analysis of variance (ANOVA) test of Rockwell hardness test 


\section{Discussion}

In this study, tensile strength test usually investigates the ultimate strength and the resistance of material to catastrophic failure [11,12]. It has been found that increase the tensile strength and mechanical properties of heat cured denture base acrylic is improved depending on inter polymer chain and cross-linking agent available in materials [13]. To increase dimensional stability and fixation against MRI wave leading to changes in pole direction and reduction in the magnetic effect [14].

The results shown in Figure 6 evaluated by the existence of ferromagnetic substances in pink acrylic increase magnetization, and for Clear acrylic explain by existence of more spaces in between polymer chain [15]. And the results shown in Table 2 explain basically by the different composition of the two types of acrylic (Pink, Clear) [16].

Surface hardness (Rock Well) test is the test of materials resistance to indentation [17]. The use of ((Scale L)) is for plastic and semi-plastic material for evaluation of hardness of a rigid substance [18].

Although in clinical use, denture base acrylic resin material immersed in saliva, water, and aqueous cleansing lead to increase in hardness, with high value for (Heat cured) acrylic resin [19,20].

The result obtains in Figure $7 \mathrm{~A}-\mathrm{B}$ is directly proportional to the increase of magnetic resonance depending on precession or lamer frequency which is directly proportional to the strength [21]. The results also shown in Table 4 which show a significant difference at four periods of time is explained by Geometric distortion, which arise from a variety of factors, a part of it from chemical and susceptibility differences [22].

\section{Conclusion}

Exposure to (MRI) at different periods of time lead to change in physical properties of denture base material and this change happen at different levels and degree in addition to change in the order of arrangement of atoms within same molecules which result in increasing vibration of bands in between two atoms without alter main atom and no change chemically has happened.

\section{References}

[1] Nagar A., : Magnetic Resonance Imaging (MRI). www.radiologyinfo.org.

[2] Bushong SC : Magnetic Resonance Imaging (MRI) Physical and Biological Principles, Mosby, 4th Ed., Philadelphia. 2003.

[3] Allan M., Feat R., Gledhill M., Hurrell M., Olivered N., Tremewan R : Magnetic Resonance Imaging Safty Guideline. Magne. Resona. Imag. J. 2002 ; 1: 97-101.

[4] Sivasubramanian V., Priyal S., Murali R : Application of Pulsed Magnetic Field in Improving the Quality of Biomass. Alg. Biom. Utln. J. 2011 ; 1:1-0.

[5] Edward MB., Taylor MR., Shellock GF : Prosthetic heart valves : evaluation of magnetic field interaction, heating, and artifacts at 1.5 tesla. Magne. Resonan. Img. J. 2000 ; 12: 363-369.

[6] Tayama S., Kunieda E., Okuy N., Takedu A., Takedu T : Stresostatic radiosurgery with an upper partial denture. Keio. $J$. Med. 2009 ; 58: 120-123.

[7] Fronz J., Wippold J : Head and neck imaging : the role of (CT) and (MRI). Magne. Resonan. Img. J. 2001 ; 25: 453-456.

[8] Anusavice KJ : Denture base resins science of dental material, Philips (1996). Pennsylvania, PA : 211-253.

[9] Ozkan YK., Sertgoz A., Geodic H. Effect of thermocycling on tensile strength of six silicon based resident denture liners. $J$. Prosthet. Dent. 2003 ; 89 : 303-310.

[10] Issac RG : Some properties of acrylic denture base materials processed by two different techniques : atom parative study. (1992) : M.Sc. Thesis. Collage of Dentistry.

[11] Carlos NB, Hawison A. : the effect of untreated (UHMWPE) beads on some properties of acrylic resin denture base material. Dent. J. 1997 ; 25: 59-64.

[12] Rached RN., Pouer JM., Autominha A., Cyry BD. Repair strenth of the polymerized, micromore, and conventional heat polymenized acrylic resins. J. Prosth. Dent. 2004 ; 92: 79-82.

[13] Kawaguchi T., Lassila LV., Vallittu PK:magnetic resonance imaging used in different application. Magne.Resona.Img.J.2009;31:123-133.

[14] Bagheri HM., Hosseini MM, Emami JM., Forough AA : Metallic artifact in (MRI) after removal of implants. Euwp. J. Rodio. 2010 ; 20: 1016-1020.

[15] Leon BT. Cury AD., Cunha R., Garcia MR : Water sorption solubility and tensile bond strength of resion denture lining materials polymerized by different methods after thermal cycling. J. Prosthet. Dent. 2005 ; 93; 281-297.

[16] Craig RG., Power JM., Wataha JC : Dental material : properties and manipulation 2004. $8^{\text {th }}$ ed. Mosby Comp., 124-125.

[17] Seo RS., Murata H., Hong G., Eduordo C., Hamada T. : Influnce of thermal and mechanical stress on the strength of an intact and relined denture bases. J. Prosthet. Dent. (2006) ; 96: 59-67.

[18] Machado C., Sanchez E., Azer SS, Uribe JM : Comparative study of the transverse strength and hardness of three denture base materials. J. Dent. 2001 ; 35: 930-933.

[19] Neppelenbroek KH., Pararina AC., Vergani CE., Giampaolo ET. Hardness of heat polymerized acrylic resins after dis infection and long term water immersion. J. Prosthe. Dent. 2005 ; 93: 171-6.

[20] Mese A., Kabraman G., Guzel G : Effect of storage duration on the hardness and tensile bond strength of silicon- and acrylic resin based resilient denture liners to a processed denture base acrylic resin. J. Prosthet. Dent. 2008 ; 99: 155-159.

[21] Huettel S : Functional magnetic resonance imaging application of single proton imaging : $2010 ; 1^{\text {st }}$. ed., Elsevier. Durham.

[22] Wang D., Strugnell W., Cani G., Doddrell MD., Slaughter R : Geometric distoration in clinical (MRI) system evaluation using a 3D phantom . J. Magne. Resona.Imag. 2004 ; 22: 1211-1217. 